\title{
ANALISIS EFEKTIVITAS EXPO DAN OPEN HOUSE SERTA MINAT CALON SISWA INDONESIA DAN ASING PADA ENGLISH FIRST (EF) MALANG
}

\author{
Michelle Nikita Jusuf \\ Alumni Universitas Ma Chung
}

\begin{abstract}
ABSTRAKSI
Pada jaman sekarang, dapat diketahui bahwa dalam menghadapi era globalisasi ma syarakat dituntut untuk memiliki bekal yang berguna seperti kemampuan dalam berbahasa asing seperti bahasa Inggris. Banyak lembaga pendidikan bahasa asing juga yang telah didirikan di Indonesia demikian juga di Kota Malang misalnya saja English First (EF), The British Institute (TBI), Lembaga Bahasa dan Pendidikan Profesional LIA (LBPP LIA). Banyak lembaga pendidikan bahasa yang mengadakan promosi dalam menjaring siswanya dan salah satu di antaranya adalah English First (EF). Terdapat dua masalah penelitian yang diteliti, yakni: Pertama, bagaimana perbedaan efektivitas expo dan open house terhadap peningkatan jumlah siswa pada EF. Kedua, bagaimana perbedaan efektivitas expo dan open house pada minat calon siswa Indonesia dan Asing pada EF. Adapun penelitian ini menggunakan metode kuantitatif.

Pada penelitian ini expo terlihat lebih efektif dan banyak mendapatkan murid saat diadakan event ini dibandingkan dengan open house. Dalam expo juga bisa didapatkan keuntungan yaitu bisa lebih dekat dengan calon customer dan mendapatkan respon yang lebih bagus dibandingkan dengan menggunakan pendekatan dengan menggunakan email atau telepon. Dari sisi efektivitas expo dan open house pada minat calon siswa Indonesia dan siswa Asing pada EF ternyata tidak memiliki perbedaan yang signifikan. Dalam hal ini berarti kedua calon siswa baik Indonesia maupun asing juga sama-sama memiliki minat untuk belajar di EF.

Kata kunci: efektivitas, minat, expo, open house, calon siswa
\end{abstract}

\section{ABSTRACT}

At this time, it is known that in the era of globalization people are required to have such a useful provision like the foreign language skills such as English. Many foreign language education institutions also have been established in Indonesia as well as in Malang for example English First (EF), The British Institute (TBI), Institute for Language and Education Professionals LIA (LBPP LIA). Therefore, many language institutions that hold promotions in attracting students and one of them is English First (EF). There are two research problem: First, how is the differences in the effectiveness of the expo and open house to increase the number of students at the EF. Second, how is the differences in the effectiveness of expo and open house on the interests of prospective Indonesian and foreign students at EF. As this study used quantitative methods.

In this research expo looks much more effective at getting students while held this event compared to the open house. In the expo can also be obtained advantages that could be closer to prospective customers and get a better response compared with the approach using the email or telephone. Effectiveness of the expo and open house at the interests of prospective Indonesian students and foreign students at the EF did not have a significant difference. In this case means that the two candidates both Indonesian and foreign students also have a passion for learning in EF.

Keywords: effectiveness, intention, expo, open house, prospective students

\section{PENDAHULUAN}

Pada jaman sekarang, dapat diketahui bahwa dalam menghadapi era globalisasi masyarakat dituntut untuk memiliki bekal yang berguna seperti kemampuan dalam berbahasa asing seperti bahasa Inggris. Menurut Steele, Oishi, O’Connor, dan Silva (2009) jika tidak ditekankan dari sekarang mengenai multilingual dan kompetensi lintas budaya di sekolah maka siswa bisa mengalami kerugian saat nantinya memasuki dunia bisnis. Selain itu telah dibuktikan juga melalui survey yang dilakukan oleh Steele dari 581 lulusan sekolah bisnis yang membutuhkan waktu 4 semester untuk mempelajari bahasa asing, mayoritas dari responden tersebut mengatakan bahwa ilmu pengetahuan dan 
kemampuan dalam berbahasa asing dan budaya telah memberikan mereka keuntungan yang kompetitif dalam karirnya sehingga membuat tingkat kompetensi mereka menjadi meningkat. Hal ini bisa dilihat pada Gambar 1.

Seperti yang disebutkan oleh Keating (2012), bahasa Inggris merupakan salah satu isu dalam sistem pendidikan yang ada di Indonesia yang mana cenderung menghasilkan siswa dengan praduga cara yang akan diajarkan. Seringkali ini berarti peserta didik pasif mengharapkan untuk menyerap informasi dari guru yang merupakan pusat dari kelas. Pembelajaran bahasa yang paling efektif adalah berada dalam lingkungan di mana siswa aktif merasa bebas untuk berpartisipasi, terlibat dan mengajukan pertanyaan, sebuah lingkungan di mana siswa tahu bahwa membuat kesalahan adalah cara terbaik untuk belajar dan di mana membuat kesalahan tidak membuat mereka kehilangan muka.

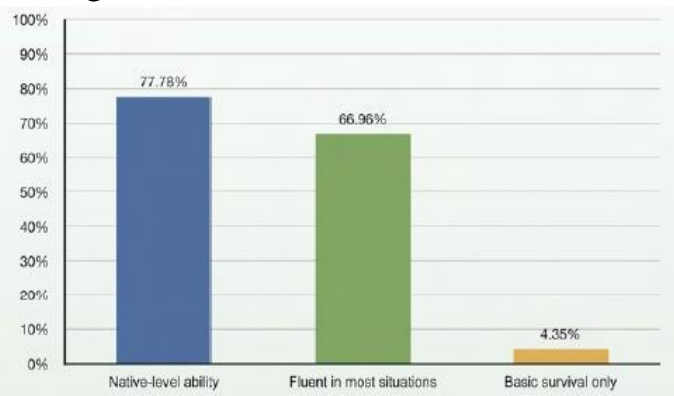

Gambar 1: Laporan Persentase Keuntungan yang Signifikan Dalam Bisnis Karena Kemampuan Bahasa Asing, Berdasarkan Tingkat Kemahiran

Sumber: "The Competitive Advantage of Foreign Language and Cultural Knowledge”, The Modern Language Journal 88 no. 3 (2004)

Banyak lembaga pendidikan bahasa asing juga yang telah didirikan di Indonesia demikian juga di Kota Malang misalnya saja English First (EF), The British Institute (TBI), Lembaga Bahasa dan Pendidikan Profesional LIA (LBPP LIA). Maka dari itu, banyak lembaga pendidikan bahasa yang mengadakan promosi dalam menjaring siswanya dan salah satu di antaranya adalah English First (EF).

EF sebagai penyedia jasa pendidikan bahasa adalah perusahaan global dengan sumber daya internasional yang hanya bisa disaingi oleh beberapa sekolah di Indonesia. Metode pengajaran dari $\mathrm{EF}$ telah berhasil digunakan di seluruh dunia dan terus menerus dikembangkan oleh tim internasional untuk memastikan konsumen/siswanya selalu mendapatkan yang terbaik selama menempuh pembelajaran dengan EF.

Sejak didirikan pada tahun 1999 untuk mendapatkan siswanya EF Malang banyak melakukan promosi dengan menggunakan metode expo dan open house di mana saat diadakan kedua event tersebut banyak diadakan tes gratis untuk mengukur kemampuan masingmasing orang. Dengan adanya placement test bisa digunakan oleh para orang tua untuk mengetahui seberapa banyak pengetahuan mengenai bahasa inggris yang dimiliki sang anak. Dalam expo dan open house juga biasanya diberikan diskon untuk yang mendaftar ke EF sehingga bisa mendapatkan harga yang lebih hemat. Melalui expo dan open house ini, EF Malang telah mendapatkan banyak siswa dan biaya yang dikeluarkan untuk kedua event ini tentunya tidaklah sedikit. Oleh karena itu adalah menarik untuk mengetahui efektivitas dari kedua bentuk promosi ini untuk mendapatkan siswa.

\section{KAJIAN TEORI}

Komunikasi Pemasaran Event

Setiap event yang diselenggarakan memiliki tujuan tertentu. Salah satu tujuannya adalah memasarkan event pada target sasarannya yang diharapkan akan hadir dalam event yang diadakan. Kunci utamanya adalah pengunjung mengetahui manfaat apa yang akan didapat melalui sebuah event (Noor, 2009).

Tujuan dilakukan pemasaran adalah untuk mendatangkan jumlah pengunjung yang mencapai target atau bahkan melebihi target yang telah ditetapkan. Hal ini dikarenakan jumlah pengunjung yang sesuai atau melebihi target adalah salah satu kesuksesan sebuah event (Noor, 2009).

Pemasaran event menurut Noor (2009) tidak sekedar menempelkan poster pada tempattempat yang strategis dan berharap akan banyak orang melihat dan tertarik untuk datang ke event, tetapi harus diperhatikan apa saja yang harus dilakukan untuk mendatangkan orang-orang tersebut. Beberapa cara yang perlu diperhatikan adalah:

1. Mengetahui sebanyak mungkin hal tentang pangsa pasar event; 
2. Memilah pangsa pasar sesuai segmen yang ada;

3. Teknik apa yang tepat untuk menarik pangsa pasar datang ke event;

4. Menetapkan harga sesuai dengan segmen yang telah ditetapkan.

Inti dari kegiatan pemasaran suatu event adalah untuk menginformasikan manfaat, atau alasan mengapa calon peserta atau pengunjung merespon untuk berpartisipasi dan datang ke sebuah event. Menurut Pudjiastuti (2010), event harus dibuat semenarik mungkin untuk merangsang media agar mau meliput. Caranya, acara tersebut harus dibuat unik, lain daripada yang lain, dan menggunakan kiat-kiat tertentu yang menarik untuk media, seperti memanfaatkan selebritas sebagai ikon, memberikan servis kepada khalayak, dan mengundang khusus pihak media untuk meliput acara yang diadakan.

Nilai jual sebuah event tergantung dari bobot event itu sendiri serta keunikan event yang terlihat dari tema event tersebut. Maka sebuah event harus memiliki identitas, karena di situlah awal mula image terbentuk dalam benak audience. Berdasarkan teori komunikasi mengenai identitas oleh Michael Hect, identitas merupakan penghubung utama antara individu dan masyarakat, dan komunikasi merupakan mata rantai yang memungkinkan hubungan ini terjadi. Teori ini menjelaskan bahwa komunikasi merupakan alat untuk membentuk identitas dan juga mengubah mekanisme. Identitas, baik dalam pandangan diri maupun orang lain, dibentuk ketika kita secara sosial berinteraksi dengan orang lain dalam kehidupan (John dan Foss, 2009).

Pudjiastuti dalam buku Special Events (2010), mengatakan bahwa agar sebuah event mendapatkan publisitas yang optimal, bagian publikasi harus melakukan hal-hal sebagai berikut:

a. Upayakan mendapat liputan luas dari media massa, baik cetak, elektronik, maupun media interaktif, misalnya dengan konferensi media atau pers, news release, atau liputan langsung dari pihak media.

b. Mengundang media untuk meliput ajang khusus.

c. Mempublikasikan event sebelum, selama, dan setelah pelaksanaan, agar acara, perusahaan, produk, maupun pihak-pihak yang terlibat mendapat liputan terus menerus dari media massa. d. Siapkan secara teknis segala keperluan peliputan, seperti media room, listrik, faksimile, dan komputer untuk online.

e. Siapkan release, foto-foto, gambar, dan media kit untuk melengkapi keperluan media massa dalam penulisan berita. Siapkan foto atau rekaman pelaksanaan event untuk memenuhi permintaan media massa.

Inti dari penjelasan di atas adalah sebuah event akan menarik perhatian target pengunjung apabila acara tersebut dibuat semenarik mungkin sehingga media bersedia untuk meliput. Selain itu juga dibutuhkan perencanaan yang matang demi kelancaran proses acara, seperti persiapan data-data yang dibutuhkan oleh media maupun pengunjung.

Event

Event merupakan salah satu strategi pemasaran yang biasa digunakan untuk memperkenalkan sebuah merek atau produk kepada masyarakat luas. Hal ini menjadikan event sebagai sebuah alternative cara untuk menyampaikan pesan kepada khalayak luas yang efektif dan tepat dan untuk memberikan informasi tentang penyelenggaraan event tertentu.

Event memiliki nilai lebih dalam menja lin hubungan dengan khalayak secara langsung yang bertujuan untuk membentuk sebuah opini public. Hal ini dapat dilakukan dengan membentuk event sebagai sarana bagi masyarakat melalui peristiwa-peristiwa yang dirancang khusus untuk mengkomunikasikan pesan tertentu kepada audience sasaran. Noor (2009) mendefinisikan event sebagai suatu kegiatan yang diselenggarakan untuk memperingati hal-hal penting sepanjang hidup manusia, baik secara individu atau kelompok yang terikat secara adat, budaya, tradisi, dan agama yang diselenggarakan untuk tujuan tertentu serta melibatkan lingkungan masyarakat yang diselenggarakan pada waktu tertentu.

Kelebihan sebuah event adalah kemampuannya dalam membangkitkan dan mengarahkan khalayak kepada sebuah produk tertentu. Event merupakan hal yang cukup penting dalam mendukung aktivitas promosi. Untuk mengkomunikasikan produk pada event tertentu kepada masyarakat umum diperlukan strategi yang kuat sebagai cara agar event menjadi efektif bagi masyarakat sebagai bentuk aktivitas promosi.

\section{Efektivitas}

Pada dasarnya pengertian efektivitas yang 
umum menunjukkan pada taraf tercapainya hasil. Pengertian ini sering atau senantiasa dikaitkan dengan pengertian efisien, meskipun sebenarnya ada perbedaan diantara keduanya. Efektivitas menekankan pada hasil yang dicapai, sedangkan efisiensi lebih melihat pada bagaimana cara mencapai hasil yang dicapai itu dengan membandingkan antara input dan output-nya. Kata kunci efektivitas adalah efektif, karena pada akhirnya keberhasilan perusahaan diukur dengan konsep efektivitas. Arti dari efektif maupun efisien terdapat beberapa pendapat.

Menurut Peter Drucker, efektivitas berarti sejauh mana kita mencapai sasaran dan efisiensi berarti bagaimana kita mencampur sumber daya secara cermat. Efisien tetapi tidak efekt if berarti baik dalam memanfaatkan sumberdaya (input), tetapi tidak mencapai sasaran. Sebaliknya, efektif tetapi tidak efisien berarti dalam mencapai sasaran menggunakan sumber daya berlebihan atau dikatakan ekonomi biaya tinggi. Keadaan terparah adalah ketika tidak ef isien dan juga tidak efektif, artinya ada pemborosan sumber daya tanpa mencapai sasaran.

Minat

Minat merupakan salah satu unsur kepribadian individu yang memegang peranan penting dalam perbuatan. Minat seseorang dapat diketahui dari pernyataan senang atau tidak senang ataupun suka atau tidak suka terhadap suatu objek tertentu. Minat tidak dibawa sejak lahir melainkan diperoleh kemudian.

Selain itu salah satu faktor utama untuk mencapai sukses dalam segala bidang, baik berupa studi, kerja, hobi atau aktivitas apapun adalah minat. Hal ini karena dengan tumbuhnya minat dalam diri seseorang akan melahirkan perhatian untuk melakukan sesuatu dengan tekun dalam jangka waktu yang lama, lebih berkonsentrasi, mudah untuk mengingat dan tidak mudah bosan dengan apa yang dipelajari.

Kemudian menurut Sukartini (dalam Fitri 2010) analisa minat dapat dilakukan terhadap hal-hal sebagai berikut:

a. Keinginan untuk mengetahui/memiliki sesuatu

b. Objek-objek atau kegiatan yang disenangi

c. Jenis kegiatan untuk mencapai hal yang disenangi

d. Usaha untuk merealisasikan keinginan atau rasa senang terhadap sesuatu.

Seseorang konsumen tidak dengan sendirinya memiliki keputusan dalam pembelian barang atau jasa. Terlebih dahulu konsumen mencari informasi dari orang terdekat atau orang yang benar-benar dipercaya untuk membantunya dalam pengambilan keputusan.

Menurut Ferdinand (dalam Arista, 2011), minat beli dapat diidentifikasikan melalui indikator-indikator sebagai berikut:

a. Minat transaksional, yaitu kecenderungan seseorang untukmembeli produk.

b. Minat referensial, yaitu kecenderungan seseorang untuk mereferensikan produk kepada orang lain.

c. Minat preferensial, yaitu minat yang menggambarkan perilaku seseorang yang memiliki preferensi utama pada produk tersebut. Preferensi ini hanya dapat diganti jika terjadi sesuatu dengan produk preferensinya.

d. Minat eksploratif, minat ini menggambarkan perilaku seseorang yang selalu mencari informasi mengenai produk yang diminatinya dan mencari informasi untuk mendukung sifat-sifat positif dari produk tersebut.

\section{PEMBAHASAN}

EF Malang

Salah satu cabang franchise dari English First Nusantara adalah EF Malang. EF Malang adalah sekolah EF yang terbesar kedua di Jawa Timur setelah EF Surabaya. EF Malang ini bertempat di Jalan Merbabu 38. Berdiri pada 9 September 1999, EF Malang mendapatkan tanggapan positif dari masyarakat Malang karena Malang adalah kota pelajar, di mana sebagian besar masyarakat adalah pelajar yang berasal dari kota-kota lain. EF Malang menggunakan guru penutur asli dan didukung pula oleh sejumlah guru lokal berpengalaman dan bersertifikasi internasional.

Kerangka Pemikiran

Hipotesis yang didapat oleh peneliti mengenai penelitian ini adalah adanya perbedaan efektivitas expo dan open house terhadap peningkatan jumlah siswa pada lembaga pendidikan EF serta adanya perbedaan efektivitas expo dan open house pada minat calon siswa Indonesia dan calon siswa Asing pada lembaga pendidikan EF. Efektivitas promosi dapat dilihat dari segi banyaknya siswa yang masuk ke lembaga pendidikan EF sehingga bisa diketahui keefekt ivitasan dari promosi yang dilakukan.

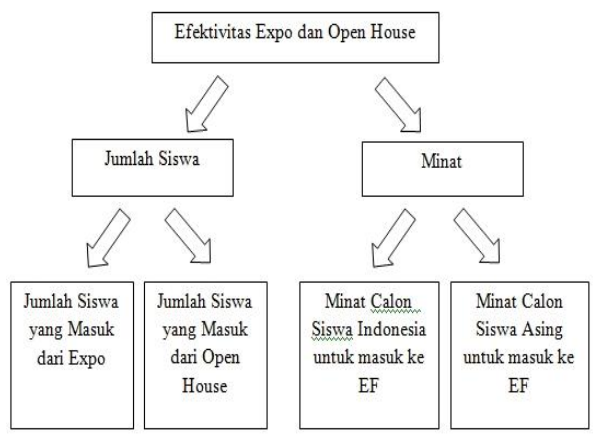


Gambar 1. Kerangka Pemikiran

Metode yang digunakan oleh peneliti adalah secondary data analysis. Hal ini berupa data mengenai jumlah siswa yang masuk karena expo dan open house dalam kurun waktu selama tahun 2011-2012. Kemudian peneliti juga menggunakan survey method. Metode survey ini adalah metode mencari informasi dari responden menggunakan pertanyaan secara verbal dan non verbal. Metode ini digunakan karena peneliti ingin menggunakan kuisioner untuk mengetahui perbedaan efektivitas expo dan open house pada minat calon siswa Indonesia dan Asing pada EF. Alasan menggunakan kuisioner adalah untuk mendapatkan informasi mengenai masalah secara serentak.

Teknik analisis data yang penulis gunakan adalah dengan menggunakan uji $\mathrm{T}$ Beda Rata-rata 2 Sampel Independen. Uji t Beda Rata-rata 2 Sampel Independen ini merupakan metode yang digunakan untuk mengetahui ada atau tidaknya perbedaan rata-rata antara dua kelompok sampel yang tidak berhubungan.

Teknik analisis uji beda t Beda Rata-rata 2 Sampel Independen tersebut digunakan dalam program SPSS yang menghasilkan output seperti tabel di bawah ini:

a. Analisis Efektivitas Expo dan Open House

Tabel 1. Output SPSS

\begin{tabular}{|rl|r|r|r|c|}
\hline & Group Statistics \\
& Event & N & Mean & $\begin{array}{c}\text { Std. } \\
\text { Deviation }\end{array}$ & $\begin{array}{c}\text { Std. Error } \\
\text { Mean }\end{array}$ \\
\hline Efektivitas & $\begin{array}{l}\text { Open } \\
\text { House }\end{array}$ & 4 & 182.00 & 77.859 & 38.929 \\
& Expo & 4 & 612.75 & 87.546 & 43.773 \\
\hline
\end{tabular}

Independent Samples Test

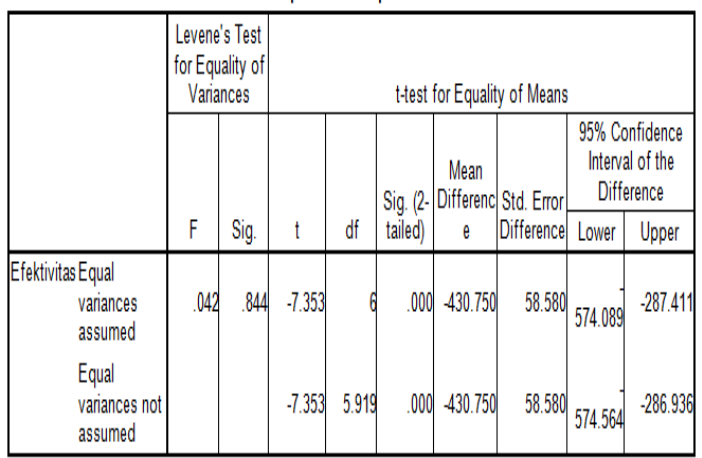

Sumber: Olahan Output SPSS

Dari hasil output yang diteliti dapat disimpulkan bahwa ada perbedaan efektivitas expo dan open house terhadap peningkatan jumlah siswa pada EF. Dalam hal ini, expo terlihat lebih efektif dan banyak mendapatkan murid saat diadakan event ini dibandingkan dengan open house. Dalam expo juga bisa didapatkan keuntungan yaitu bisa lebih dekat dengan calon customer dan mendapatkan respon yang lebih bagus dibandingkan dengan menggunakan pendekatan dengan menggunakan email atau telepon. Selain itu juga customer potential juga akan bisa mendekati kita karena ingin mengetahui produk yang dimiliki, itu akan lebih memudahkan untuk berbicara mengenai produk dan jasa yang dimiliki (Expo Surprise for Credit Management Company, 2009). Kemudian dengan diadakannya expo di tempat umum seperti mal lebih efektif dalam mendapatkan calon siswa karena dilihat dari banyaknya orang yang datang ke tempat ters ebut.

b. Analisis Minat Calon Siswa Indonesia dan Asing

Tabel 2 , Output SPSS

Group Statistics

\begin{tabular}{|c|c|c|c|c|c|}
\hline & Siswa & N & Mean & Std. Deviation & $\begin{array}{c}\text { Std. Error } \\
\text { Mean }\end{array}$ \\
\hline \multirow[t]{2}{*}{ Total } & Siswa Indonesia & 50 & 46.06 & 4.002 & .566 \\
\hline & Siswa Asing & 50 & 46.64 & 3.237 & .458 \\
\hline
\end{tabular}


Independent Samples Test

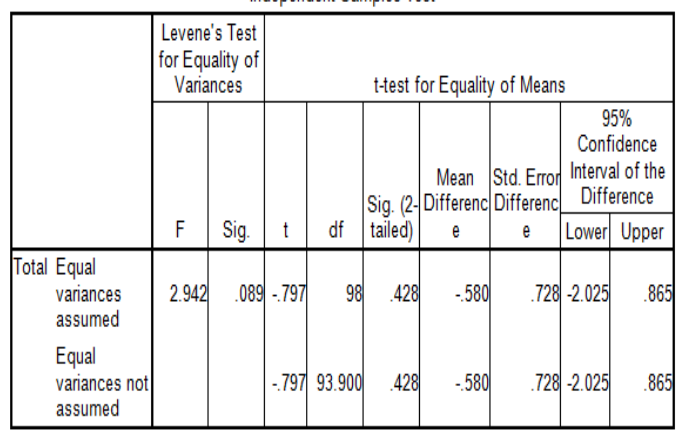

Sumber: Olahan Output SPSS

Dari hasil output yang diteliti dapat disimpulkan bahwa tidak ada perbedaan yang signifikan dari efektivitas expo dan open house terhadap minat calon siswa Indonesia dan Asing pada EF. Dalam hal ini berarti kedua calon siswa baik Indonesia maupun asing juga sama-sama memiliki minat untuk belajar di EF. Hal ini dikarenakan untuk calon siswa Indonesia dan calon siswa Asing terutama dari negara Korea, Jepang, dan Malaysia; bahasa Inggris merupakan bahasa tambahan selain bahasa ibu mereka. Seperti di Korea, bahasa Inggris merupakan salah satu isu dalam sistem pendidikan mereka (Eun Cho, 2004) dikarenakan adanya beberapa perbedaan mulai dari perbedaan bahasa, cara bicara, cara penulisan dan juga budayanya. Di sana banyak orang tua yang rela untuk menginvestasikan uang dan waktunya untuk membantu anak-anaknya supaya lebih mahir dalam berbahasa Inggris dan mereka juga memasukkan anaknya ke dalam lembaga pendidikan bahasa Inggris untuk makin mempercepat pemahaman anak-anak mereka akan bahasa Inggris. Begitu juga yang ada di kota Malang di mana ada juga calon siswa asing y ang berminat untuk masuk ke EF untuk memperdalam kemampuan bahasa Inggris mereka.

\section{KESIMPULAN}

Hasil dari penelitian ini menunjukkan bahwa yang pertama terdapat perbedaan efektivitas expo dan open house terhadap peningkatan jumlah siswa pada EF. Dalam hal ini yang lebih dominan adalah expo yang banyak menghasilkan siswa untuk masuk ke EF. Hal ini bisa menjadi salah satu peluang dari EF dalam menjaring siswa masuk dikarenakan expo ini diadakan di tempat umum seperti mal sehingga banyak masyarakat umum yang datang dan bisa mendaftarkan anak-anak mereka menjadi siswa EF terlebih lagi dengan adanya program diskon uang masuk saat event ini berlangsung. Kemudian yang kedua, tidak terdapat perbedaan yang signifikan pada efektivitas expo dan open house pada minat calon siswa Indonesia dan Asing pada EF. Dari hal ini minat dari calon siswa Asing pada EF sedikit lebih besar dari calon siswa Indonesia dilihat dari data yang didapat oleh peneliti melalui kuisioner yang sudah disebarkan.

\section{DAFTAR PUSTAKA}

1. About EF. n.d. www.ef.co.id (diakses 15 Maret 2013)

2. Arista, E. 2011. Analisis Pengaruh Iklan, Brand Trust, dan Brand Image Terhadap Minat Beli Konsumen Telkom Speedy di Kota Semarang. Skripsi pada Jurusan Manajemen, Fakultas Ekonomi, Universitas Diponegoro, Semarang.

3. Eun Cho, B. 2004. Issues Concerning Korean Learners of English: English Education in Korea and Some Common Difficulties of Korean Students. The East Asian Learner Vol. 1(2).

4. Expo Surprise For Credit Management Company. 2009. NZ Business Vol. 23 Issue 1, p9-9, 1/2p.

5. Fitri, N. 2010. Pengaruh Minat Belajar dan Pemanfaatan Sumber Belajar Terhadap Prestasi Belajar Siswa dalam Kompetensi Menyelesaikan Siklus Akuntansi Perusahaan Jasa di SMK Negeri 3 Bandung. Skripsi pada Jurusan Akuntansi, Fakultas Ekonomi dan Bisnis, Universitas Pendidikan Indonesia, Bandung.

6. Grosse, C. 2004. The Competitive Advantage of Foreign Language and Cultural Knowledge. The Modern Language Journal 88, no.3:351-373.

7. Keating, D. 2012. Common English Language Problems of Indonesia Student. http://www.streetdirectory.com/travel_guid e/106517/languages/common_english_lang uage_problems_of_indonesian_students.ht ml (diakses 31 Januari 2013)

8. Little, J., dan K. Foss. 2009. Teori Komunikasi, Edisi 9. Jakarta: Salemba Humanika.

9. Noor, A. 2009. Manajemen Event. Jakarta: CV. Alfa Beta.

10. Pudjiastuti, W. 2010. Special Event. Jakarta: PT. Elex Media Komputindo.

11. Steele, T., L. Oishi, K. O'Connor, dan D.M. Silva. 2009. Learning World Language and Cultures in California. http://www.stanford.edu (diakses 23 Januari 2013) 